\title{
The Importance of Fire Simulation in Fire Prediction
}

\author{
RADOJE B. JEVTIĆ, Electrotechnical school "Nikola Tesla", Niš
}

Original scientific paper

UDC: 614.841 .4

\begin{abstract}
The appearance of fire in objects with lot of humans inside represents very possible real situation that could be very danger and could cause destructive consequences on human lives and material properties. Very important influence in fire prediction, fire protection, human and material properties safety could be a fire simulation in object. This simulation could give many useful information of possible fire propagation; possible and existed evacuation routes; possible and exited placing of fire, smoke, temperature conditions in object and many other information of crucial importance for human lives and material properties, such as the best places for sensors position, optimal number of sensors, projection of possible evacuation routes etc. There are many different programs for fire simulation. This paper presents complete fire simulation in Electrotechnical school Nikola Tesla in Niš in FDS.
\end{abstract}

Key words: fire, simulation, object

\section{INTRODUCTION}

The fire protection is very complex and very responsible task in every sense of human lives and material properties protection. The development of science, technique, traffic, industry so as the increasing of world population and lot of other factors confirmed noted proposition. The fire protection is probably old as much as the discovery of the fire. This discipline has developed through the history according to the science and technical development of the human society. The basic techniques for fire protection and stopping the fire propagation were consisted to the removing of the fire material, reducing and bypassing of heat and reducing of oxygen concentration in order to slow or stop the chain of the chemical reaction during the fire process. Through the history, the regulation of fire protection followed, in the most cases, the development of the science and technology. For example, the oldest document about law regulation of fire protection, also the first document about fire protection in history generally, was Hammurabi`s law (18 century B.C.) with 28 paragraphs and 16 articles. It was also considered that the first fire organize units were noted during the rule of Augustus Caesar, known as Octavian (63 year B.C.). The important role of fire protection in Europe, generally, was recorded

Author's address: Radoje Jevtić, Electrotechnical school "Nikola Tesla", Niš, Aleksandra Medvedeva 18

Paper received: 22.10.2013.

Paper accepted: 12.11.2013. from 1100 to 1600, especially in England and Russia. In America, for example, the first law regulation about fire protection showed in 1661, after huge fire in Boston. Further advancement of fire protection till today was fallowed with many new discoveries in science and technology, such as electrical fire signalization, automation fire, smoke, heat and flame detectors, central fire detection units etc.

Current level of fire protection implies the projection of complete fire system based on valued standards. It is very complex process, because, beside many start bases of projection which were predicted by law standards, regulation and references, it includes many factors which were attained according to the fire risk analyze, characteristics of the object construction, characteristics of the activities and production process in object, materials and staff in object, working and professional characteristic of personnel, etc. That implies very complex process of definition of the elementary problems, which is necessary to be done before the process of the fire system projection itself [1].

It can be concluded that the one of the most important problem in the fire systems projection is the potential fire propagation. There were several ways for eventual fire prediction according to lot of starting factors and conditions. One of the most successful and most frequently used ways for potential fire prediction is use of the simulation software and one of the most used software for this kind of problem is FDS software. 
Fire Dynam icsSimulator (FDS) presents a comutational fluid dynamics (CFD) model of fire-driven fluid flow. This software solves numerically a large eddy simulation form of the Navier-Stokes equations appropriate for low-speed, thermally-driven flow, with an emphasis on smoke and heat transport from fires. FDS is free software developed by the National Institute of Standards and Technology (NIST) of the United States Department of Commerce, in cooperation with VTT Technical Research Centre of Finland. Smokeview presents the companion visualization program that can be used to display the output of FDS. The first version of FDS was publicly released in February 2000. To date, about half of the applications of the model have been for design of smoke handling systems and sprinkler/detector activation studies. The other half consists of residential and industrial fire reconstructions. Throughout its development, FDS has been aimed at solving practical fire problems in fire protection engineering, while at the same time providing a tool to study fundamental fire dynamics and combustion. FDS is a computer program that solves equations that describe the evolution of fire. It is a FORTRAN program that reads input parameters from a text file, computes a numerical solution to the governing equations, and writes userspecified output data to files. Smokeview is a companion program that reads FDS output files and produces animations on the computer screen. Smokeview has a simple menu-driven interface. FDS does not. However, there are various programs that have been developed to generate the text file containing the input parameters needed by FDS, such as PyroSim 2012 [2].

\section{SIMULATION MODEL}

The most important tasks of the potential fire prediction is the save of human lives and after that the save of the material properties. Many objects with lot of humans inside require detail and careful approach to the projection of the appropriate fire system. The good examples of that kind of objects are schools, universities, nurseries and similar.

The Electrotechnical school "Nikola Tesla" in Niš is the secondary vocational school with more than 800 pupils and more than 100 employs. The school object itself is huge and it consists of laboratory part, classrooms part with offices, toilets, library and physical education hall. Approximate object ground surface is about $2542,91 \mathrm{~m}^{2}$. Object has three floors with maximal height about $12 \mathrm{~m}$. The laboratory part of the Electrotechnical school "Nikola Tesla" has also three floors. At the base floor of the laboratory part there are several laboratories, stuff office, carpenter room, canteen, pupils club and refrigerate devices room located. The first and the second floor have only laboratories. The classrooms part of the Electrotechnical school "Nikola Tesla" has also three floors. At the base floor, there are library, teacher's office, administrative offices (director, vice director, law service and finance service), waiting and parents receiving room. The first and the second floor of the classrooms part consist of eighteen classrooms, nine per every floor. Every floor has toilets for man and women. The physical education hall presents particular object witch is connected with school at the first floor.

Satellite view and photography of Electrotechnical school "Nikola Tesla" in Niš are presented on figures 1 and 2. Simulation model of Electrotechnical school "Nikola Tesla" in Niš in PyroSim 2012, front view, side view, back view and inside view are presented from figure 3 to figure 6 .

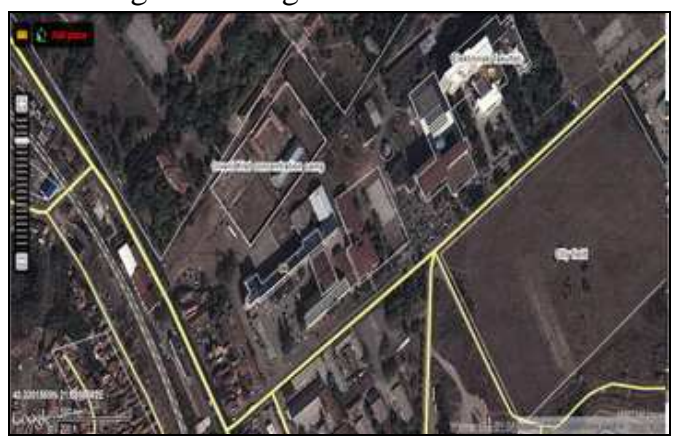

Figure 1 - Satellite view of Electrotechnical school "Nikola Tesla" in Niš

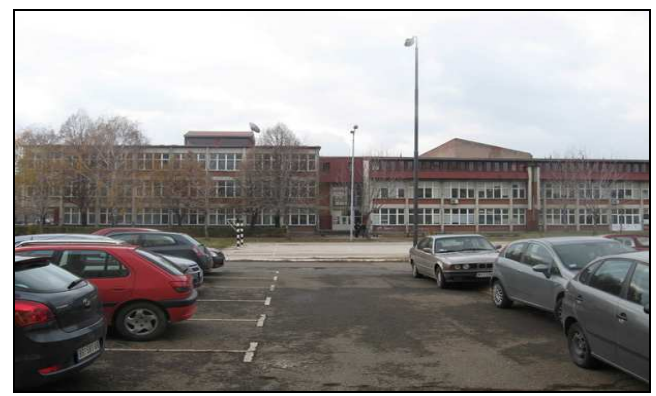

Figure 2 - Electrotechnical school "Nikola Tesla" in $\mathrm{Niš}$

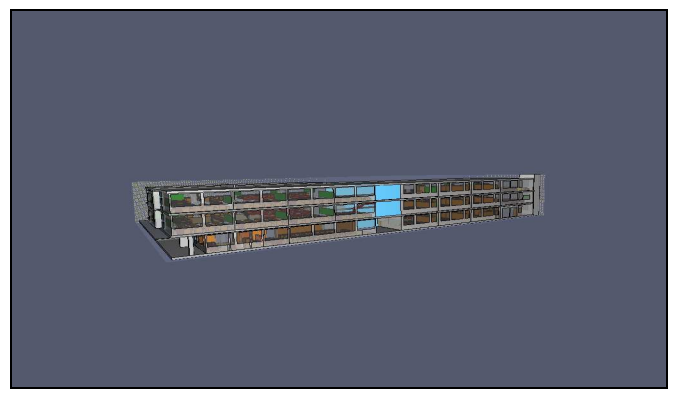

Figure 3 - Simulation model of the Electrotechnical school "Nikola Tesla" - side view in PyroSim 2012 software 


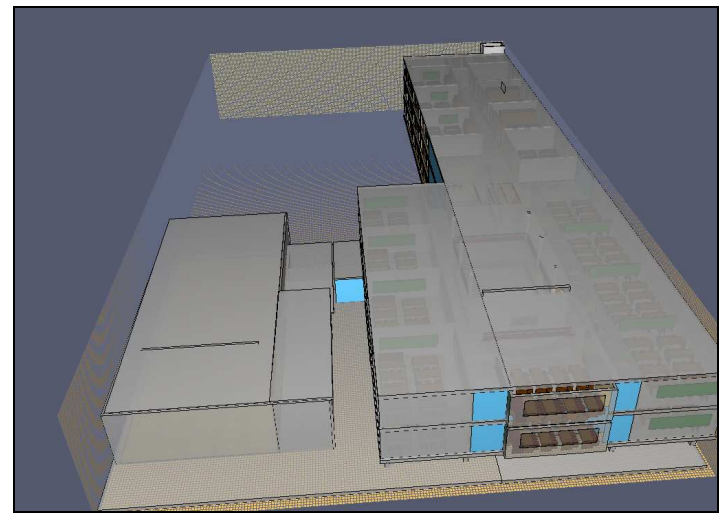

Figure 4 - Simulation model of the Electrotechnical school "Nikola Tesla" - front view in PyroSim 2012 software

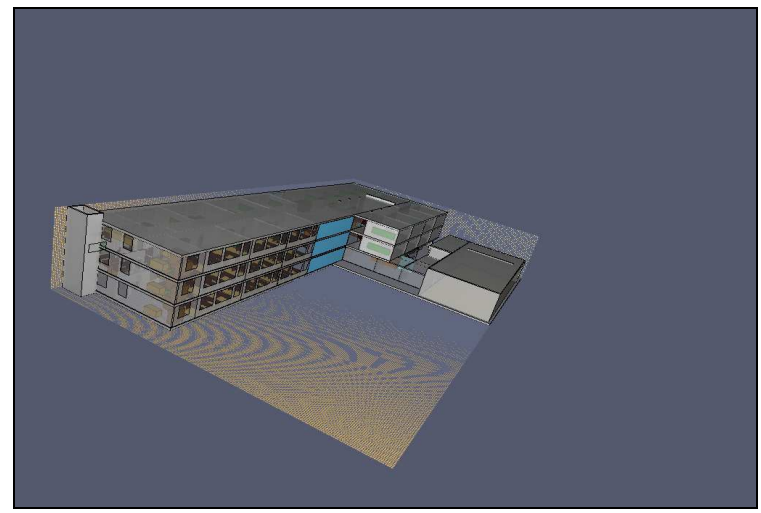

Figure 5 - Simulation model of the Electrotechnical school "Nikola Tesla" - back view in PyroSim 2012 software

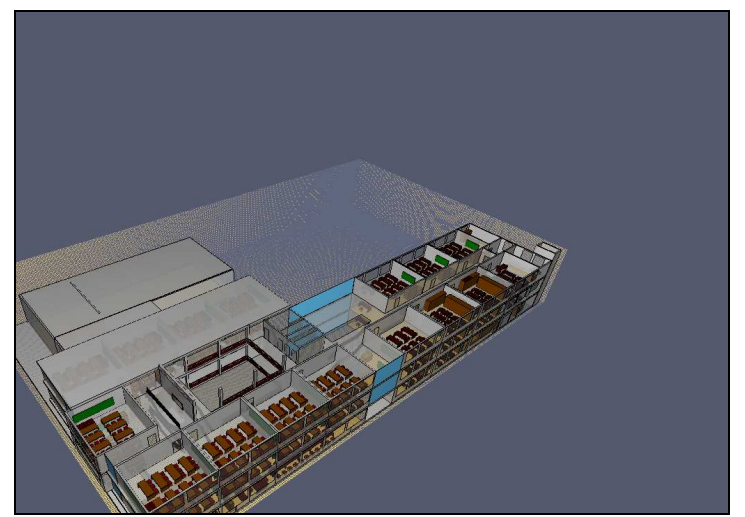

Figure 6 - Simulation model of the Electrotechnical school "Nikola Tesla" - inside view in PyroSim 2012 software

The list of objects that were located inside the school (in laboratories, carpenter room, canteen...) which could have pretty influence on fire in the whole school, with its own dimensions, number and used material) is presented on table 1 [3-6].
Table 1. The list of objects with its dimensions and material in Electrotechnical school "Nikola Tesla"

\begin{tabular}{|c|c|c|c|}
\hline $\begin{array}{l}\text { Number } \\
\text { of objects }\end{array}$ & Object & Dimensions & Material \\
\hline 967 & chair & $\begin{array}{l}0,4 \mathrm{~m} \times 0,4 \mathrm{~m} \times 0,4 \mathrm{~m} \\
(0,05 \mathrm{~m} \text { thickness })\end{array}$ & plywood \\
\hline 1 & $\begin{array}{l}\text { Carpenter } \\
\text { desk }\end{array}$ & $\begin{array}{l}3 \mathrm{~m} \times 1,5 \mathrm{~m} \times 0,75 \mathrm{~m} \\
(0,042 \mathrm{~m} \text { thickness })\end{array}$ & oak \\
\hline 76 & middle desk & $\begin{array}{l}2 \mathrm{~m} \times 0,8 \mathrm{~m} \times 0,75 \mathrm{~m} \\
(0,035 \mathrm{~m} \text { thickness })\end{array}$ & plywood \\
\hline 22 & $\begin{array}{l}\text { bigger } \\
\text { cupboard }\end{array}$ & $1,8 \mathrm{~m} \times 1 \mathrm{~m} \times 2 \mathrm{~m}$ & oak \\
\hline 37 & $\begin{array}{l}\text { smaller } \\
\text { cupboard }\end{array}$ & $1,5 \mathrm{~m} \times 1 \mathrm{~m} \times 1 \mathrm{~m}$ & oak \\
\hline 34 & floor & $\begin{array}{l}8,9 \mathrm{~m} \times 6,8 \mathrm{~m} \times \\
0,0015 \mathrm{~m}\end{array}$ & pine \\
\hline 12 & door & $\begin{array}{l}1,97 \mathrm{~m} \times 0,4 \mathrm{~m} \times \\
0,03 \mathrm{~m}\end{array}$ & aluminum \\
\hline 1 & floor & $\begin{array}{l}13 \mathrm{~m} \times 11 \mathrm{~m} \times \\
0,0025 \mathrm{~m}\end{array}$ & pine \\
\hline 6 & bench & $\begin{array}{l}4 \mathrm{~m} \times 0,25 \mathrm{~m} \times \\
0,25 \mathrm{~m}(0,1 \mathrm{~m} \\
\text { thickness })\end{array}$ & oak \\
\hline 55 & table & $\begin{array}{l}2,5 \mathrm{~m} \times 1,27 \mathrm{~m} \times \\
0,0025 \mathrm{~m}\end{array}$ & plywood \\
\hline 7 & $\begin{array}{l}\text { projector } \\
\text { panels }\end{array}$ & $2 \mathrm{~m} \times 2 \mathrm{~m}$ & cardboard \\
\hline 2670 & $\begin{array}{l}\text { pine panels } \\
\text { for walls }\end{array}$ & $1 \mathrm{~m} \times 0,04 \mathrm{~m} \times 0,005$ & pine \\
\hline 61 & doors & $\begin{array}{l}1,97 \mathrm{~m} \times 0,85 \mathrm{~m} \times \\
0,037 \mathrm{~m}\end{array}$ & plywood \\
\hline
\end{tabular}

\section{SIMULATION AND SIMULATION RESULTS}

The complete simulation of the fire propagation in the Electrotechnical school "Nikola Tesla" from Niš lasted for 600 seconds.

The fire itself was simulated with burner of $300 \mathrm{~kW}$. The simulation time was 600 seconds. On each floor, there were several locations where the simulation was realized. The reason for that was the fact that there were different construct and other material with different flammable properties on each floor.

For example, for the first floor the locations were teacher's office, administrative offices, stuff office, library, carpenter room, energetic machine laboratory and canteen. For the second and third floor, the locations were laboratories and classrooms, including computer service room and pupils working cabinet at third floor.

The big number of thermocouples simulated sensors was positioned in order to measure the biggest realized temperature in particularly room and whole object [7]. 


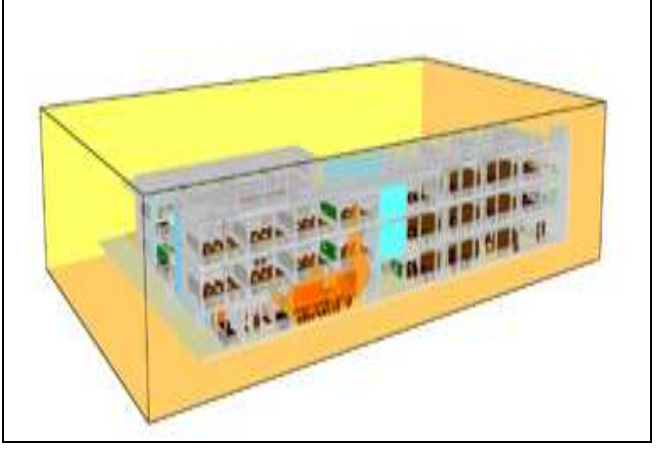

Figure 7 - Fire simulation in Electrotechnical school “Nikola Tesla” - teacher's office

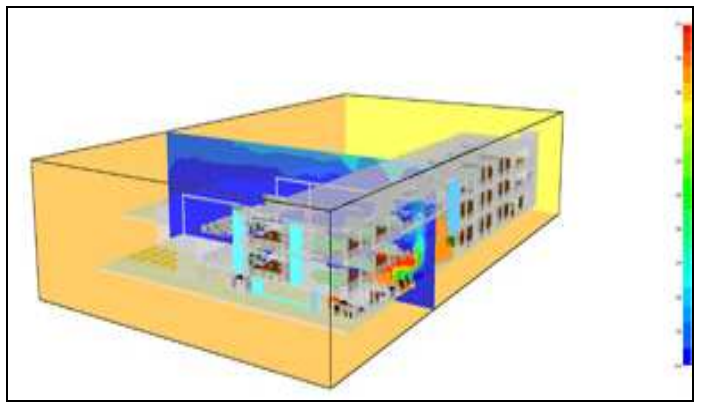

Figure 8 - Fire simulation in Electrotechnical school "Nikola Tesla" - teacher's office thermal distribution

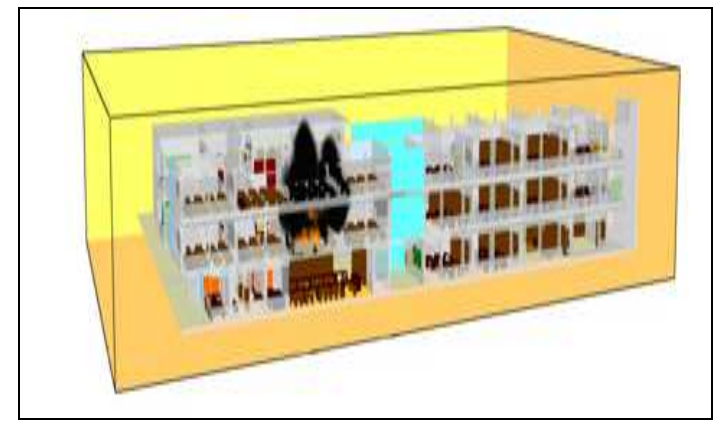

Figure 9 - Fire simulation in Electrotechnical school "Nikola Tesla" - classroom at the first floor

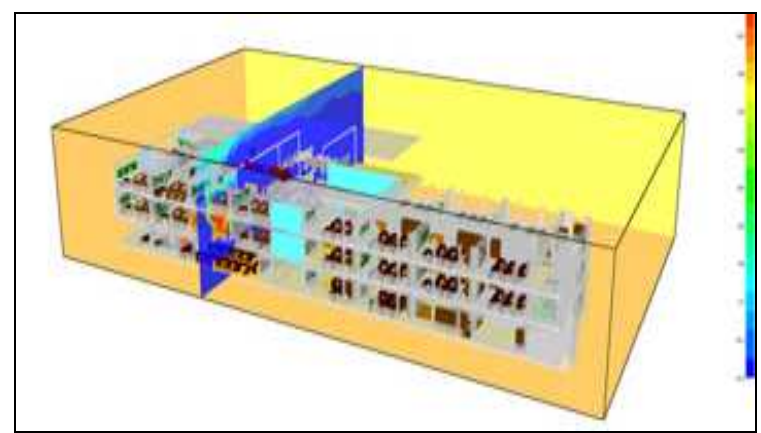

Figure 10 - Fire simulation in Electrotechnical school "Nikola Tesla" - classroom at the first floor thermal distribution

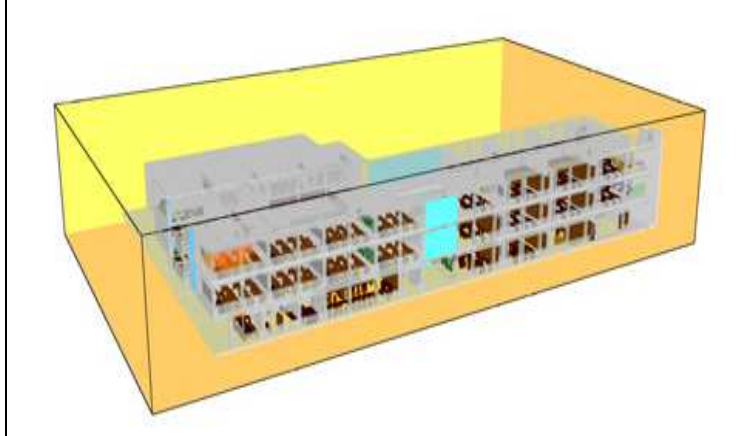

Figure 11 - Fire simulation in Electrotechnical school "Nikola Tesla" - classroom at the second floor

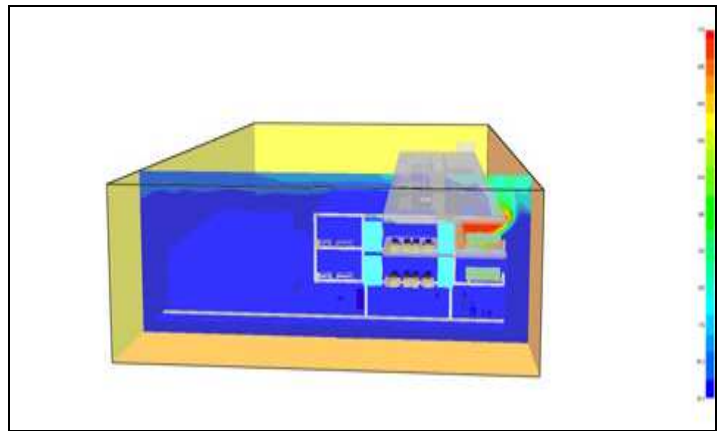

Figure 12 - Fire simulation in Electrotechnical school "Nikola Tesla" - classroom at the second floor thermal distribution

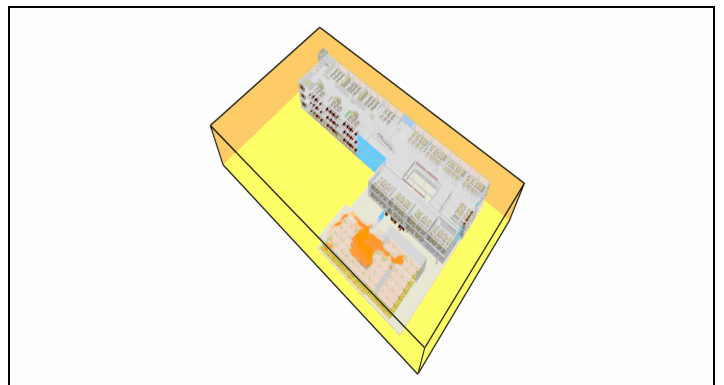

Figure 13 - Fire simulation in Electrotechnical school "Nikola Tesla" - physical education ha$l l$

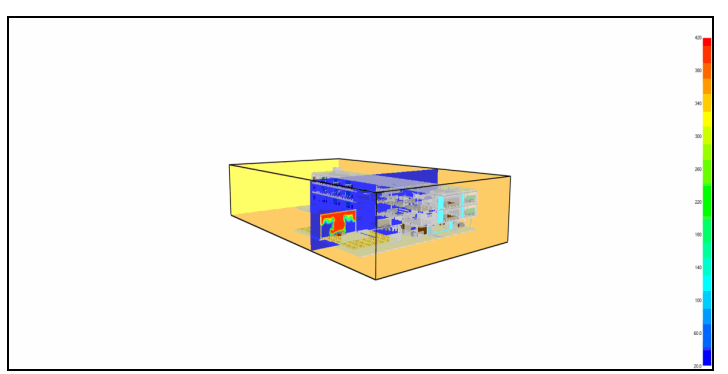

Figure 14 - Fire simulation in Electrotechnical school "Nikola Tesla" - physical education hall thermal distribution 


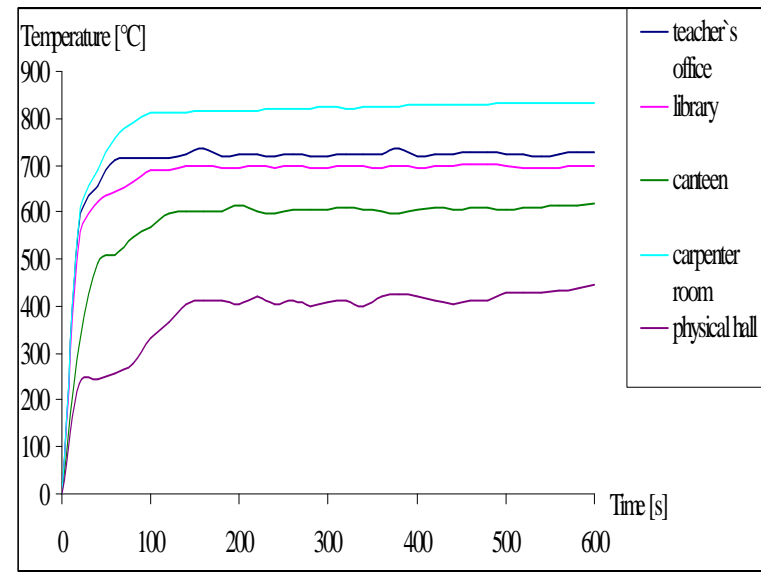

Figure 15 - Temperature from thermocouples which were positioned $10 \mathrm{~cm}$ above the burner for rooms on the base floor

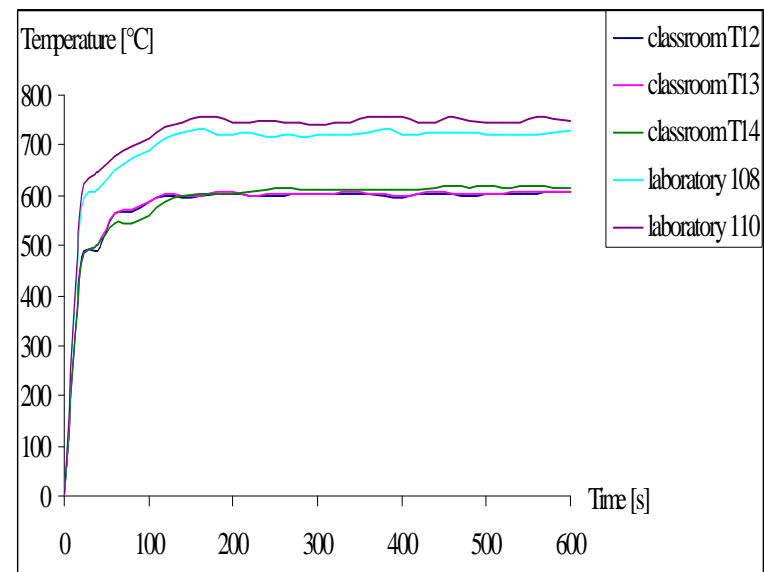

Figure 16 - Temperature from thermocouples which were positioned $10 \mathrm{~cm}$ above the burner for rooms on the first floor

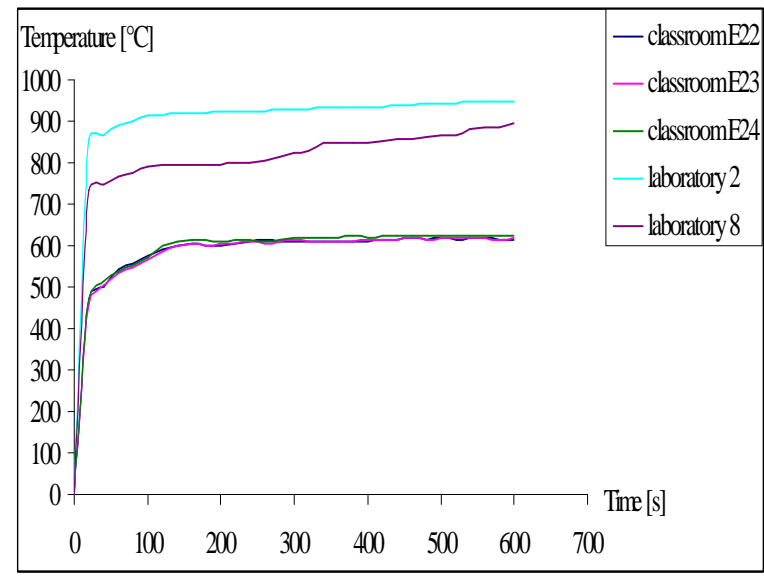

Figure 17. Temperature from thermocouples which were positioned $10 \mathrm{~cm}$ above the burner for rooms on the second floor

\section{ANALYZE OF SIMULATION RESULTS}

Simulations were lasted from 18 hours up to 23 hours. According to the different position of burner, from, for example, the desk, top of the cupboard or table, different simulation results were realized. Figures from 15 to 17 showing the temperature rising for the simulation time of 600 seconds, where the thermocouples were positioned $10 \mathrm{~cm}$ above the burner. The different results were expected according to the fact that the burners were on different material. Results for classrooms were almost the same, while the results for other rooms in the "Nikola Tesla" from Niš were different. The biggest temperature value was $949,76^{\circ} \mathrm{C}$, and it was recorded at the laboratory 2 on the second floor. It is very important to note that the biggest temperatures were recorded at the second floor-laboratory part and that all were increasing during the time of 600 seconds. The second floor was finished few years ago, according to the base building which was built in 1972, and the most of it was built from easy flammable material, such as plywood, oak three, gyps, canvas and similar. The fastest increase of temperature and smoke were also recorded at this part of school. In this paper, the analyzed results were shown for normal conditions and determinate burner. For different burner values, the similar shapes of curves were realized.

\section{CONCLUSION AND FUTURE INVESTIGATION}

The fire prediction is very important and complex task, especially for object with lot of humans in it. The detection of fire at early stage is very important; otherwise fire can cause much damage on material properties and destruction of the detector itself. The simulation of some particular object enabling determination of different parameters, for example, temperature rate, heat released rate, smoke rate and similar. Knowing this parameters and potential fire propagation is essential factor in fire detecting at early stage, construction and determination of potential evacuation routes. Simulation results can show the optimal positions for fire detectors, smoke detectors, carbon monoxide detectors, flame detectors and other fire installations in order to safe human lives, material properties and stopping of fire. These results also can show the fastest evacuation routes for human evacuating or fire stairs upgrading. In the objects with lot of humans inside it, during the fire time, many unexpected scenes could be done. For example, one these this events is panic. Taking into account the fact that the fire could case a lot of smoke with carbon monoxide, which could be much faster binds for hemoglobin other the oxygen (several hundreds times fa- 
ster), together with panic and stress behavior, could cause tragic consequences [8-12].

The achieved results present just a small part of a possible research based on non-typical electric lines in fire and burglary protection system, according to the realization of $\mathrm{PhD}$ thesis "Fire and burglary protection using non-typical electric lines" which was approved by University of Niš, evidence number 8/20-01-003/11-019. The realized results from this and similar simulations have great importance in construction and positioning of no typical electrical line as linear fire detector, in order of fire detecting at early stage.

\section{REFERENCES}

[1] Blagojević, M., Alarm systems, Faculty of Occupational Safety, Niš, 2011.

[2] Fire Dinamic Simulator, National Institute of Standards and Technology, 2010.

[3] Group of authors, Chemistry and technology handbook, Publicher working organisation Rad, Belgrade, 1987.

[4] Radošević, N., Chemists and technologist handbook, Technical book, Belgrade, 1968.
[5] Stanković D., Physics technical measurements-Sensors, Belgrade, 1997.

[6] Đukić, P., Sensors and measurement converters, Faculty in Splitu- Compartment of vocational studies, Split, 2004.

[7] Popović, M., Electrometerology laboratory practical book, Higher Electrotechnical school, Belgrade, 2001 .

[8] Jevtić, R., Blagojević, M., Linear fire detection with distance determination using coaxial cables, TELFOR 2011 conference, 2011, Belgrade.

[9] Jevtić, B. R, Blagojević, Đ. M., Simulation of the school object evacuation, Tehnika, Vol 2, pp. 365370, 2013., Belgrade.

[10] Jevtić, B. R, Blagojević, Đ. M, Linear fire detection realized by no typical electrical line, $57^{\text {th }}$ ETRAN CONFERENCE, Zlatibor, 2013.

[11] Jevtić, B. R, Ničković, T.J., Simulation of residential object evacuation, $57^{\text {th }}$ ETRAN CONFERENCE, Zlatibor, 2013.

[12] Blagojević M., Pešić D., A new curve for temperature-time relationship in compartment fire, Thermal Science, Vol. 15, Issue 2, 2011.

\section{REZIME}

\section{ZNAČAJ SIMULACIJE U PREDVIĐANJU POŽARA}

Pojava požara u objektima sa mnogo ljudi predstavlja posebnu i realnu situaciju koja može biti veoma opasna i koja može prouzrokovati destruktivne posledice po ljudske živote i materijalna dobra. Veoma važan uticaj na predviđanje požara, zaštitu od požara, ljudskih života i materijalnih dobara može imati simulacija požara u objektu. Simulacija može dati mnogo korisnih informacija o mogućem širenju požara; postojećim i mogućim rutama za evakuaciju od požara;potencijalnim pozicijama vatre i dima, temperaurnih uslova u objektu $i$ mnogim drugim informacijama koje su od krucijalne važnosti za ljudske živote i materijalna dobra, kao što su najbolje pozicije za senzore, optimalan broj senzora, projektovanje mogućih ruta za evakuaciju itd. Postoji mnogo različitih programa za simulaciju. Ovaj rad predstavlja kompletnu simulaciju požara u Elektrotehničkoj školi “Nikola Tesla” и Nišu u FDS-u.

Ključne reči: požar, simulacija, objekat 